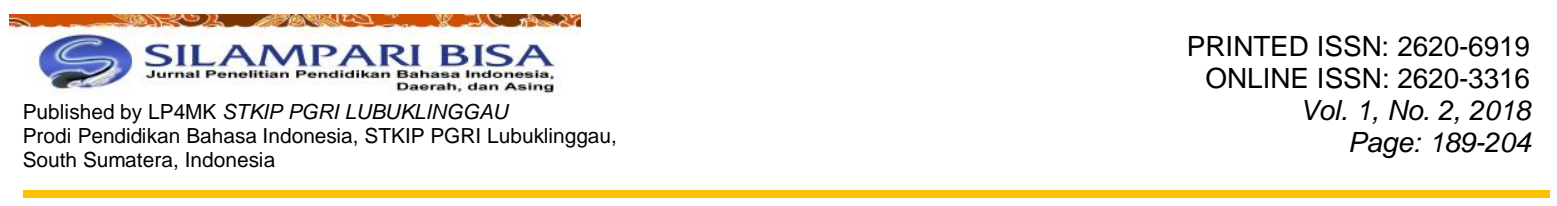

\title{
PENERAPAN MEDIA AUDIOVISUAL DALAM MENINGKATKAN KETERAMPILAN MENYIMAK DONGENG SISWA KELAS III MIS DARUL ULUM MUHAMMADIYAH BULUKUMBA
}

\author{
M. Nur Hakim \\ Program Studi Pendidikan Bahasa dan Sastra Indonesia \\ Universitas Cokroaminoto Palopo \\ Jalan Latammacelling No. 19 B Kota Palopo Sulawesi Selatan, Indonesia \\ Email:m.nur_hakim@ymail.com
}

Submitted: 20-October-2018

Accepted : 31-December-2018
Published: 31-December-2018

DOI: $10.31540 /$ silamparibisa.v1i2.79

URL: https://doi.org/10.31540/silamparibisa.v1i2.79

\begin{abstract}
Abstrak
Penelitian ini bertujuan untuk menjelaskan proses dan hasil penerapan media audiovisual dalam meningkatkan keterampilan menyimak dongeng siswa kelas III MIS Darul Ulum Muhammadiyah Bulukumba. Penelitian yang dilakukan adalah penelitian tindakan selama 2 siklus, yang meliputi tahap perencanaan, pelaksanaan, observasi, dan refleksi. Adapun teknik pengumpulan data dalam penelitian ini adalah observasi, catatan lapangan, dan tes, sedangkan teknik analisis data dilakukan secara kualitatif dan kuantitatif. Secara kualitatif, data dianalisis dari hasil observasi dan catatan lapangan, sedangkan secara kuantitatif, data dianalisis dari hasil tes yang dilakukan di setiap akhir siklus. Uji kebasahan data menggunakan triangulasi. Hasil analisis data menunjukkan bahwa: 1) selama proses penerapan media audiovisual terjadi peningkatan keterampilan menyimak dongeng yang tampak pada kemampuan siswa mengidentifikasi isi dongeng, seperti tema, penokohan, alur, latar, dan amanat, dan 2) hasil peningkatan terlihat pada ketuntasan belajar siswa yakni pada siklus I perolehan nilai rata-rata hanya 61,75 mengalami peningkatan menjadi 76,25 . Hasil tersebut disimpulkan bahwa media audiovisual dapat memberikan dampak positif dalam peningkatan keterampilan menyimak dongeng siswa kelas III MIS Darul Ulum Muhammadiyah Bulukumba.
\end{abstract}

Kata kunci: media audiovisual, keterampilan menyimak dongeng

\section{THE IMPLEMENTATION OF AUDIOVISUAL MEDIA IN IMPROVING FAIRY TALE LISTENING SKILLS CLASS III STUDENT MIS DARUL ULUM MUHAMMADIYAH BULUKUMBA}

\begin{abstract}
The aims of study was to explain the process and implementation results of audiovisual media in improving fairy tales listening of third grade MIS Darul Ulum Muhammadiyah Bulukumba students. The research was action research for 2 cycles, which included planning, implementation, observation, and reflection. The obtained research data were observation, field notes, and tests, while the data were analyzed by qualitative and quantitative method. The results of observations and field notes were analyzed qualitatively, while, the results data of tests of each cycle were analyzed quantitatively. Data wetness test using triangulation. The results of the data analysis revealed that: 1) during the process of implementing audio visual media was increase in listening to fairy tales skills, it was seen in students' ability to identify the contents of the story, such as themes,
\end{abstract}


characterizations, plot, setting, and mandate, and 2) improvement results seen in students learning completeness that in the first cycle the average score was only 61.75 , increasing to 76.25 . These results concluded that audiovisual media have a positive impact in improving fairy tales listening skill of third grade MIS Darul Ulum Muhammadiyah Bulukumba students.

Keywords: audiovisual media, fairy tales listening skills

\section{A. Pendahuluan}

Mata pelajaran bahasa Indonesia adalah salah satu pelajaran wajib yang diajarkan kepada siswa di tingkat dasar (SD/MI). Hadirnya pembelajaran bahasa Indonesia di SD/MI, karena dianggap penting untuk dikuasai oleh siswa sejak awal. Sebagaimana diketahui bahwa terdapat empat aspek keterampilan yang ada dalam pembelajaran bahasa Indonesia yaitu, keterampilan menyimak, berbicara, membaca, dan menulis (Tarigan, dalam Yanti, dkk. 2018:2). Keempat aspek tersebut dapat menunjang keberhasilan seseorang dalam proses berkomunikasi. Salah satu aspek yang penunjang keberhasilan seseorang dalam bidang bahasa dapat dilihat dari kemampuan menyimak dengan baik.

Pembelajaran keterampilan menyimak di SD/MI merupakan pembelajaran yang wajib medapat perhatian untuk terus ditingkatkan. Robertson (dalam Kirbas, 2017:2) mengungkapkan bahwa pada dasarnya siswa tingkat sekolah dasar dapat menghabiskan waktu sekitar $57 \%$ sehari untuk kegiatan menyimak. Hal ini mengindikasikan tentang pentingnya kegiatan menyimak untuk diajarkan pada siswa tingkat dasar, karena melalui pembelajaran menyimak yang efektif siswa mampu memahami materi dengan jelas.

Ampa (2015:57) mengemukakan bahwa untuk dapat berkomunikasi dengan baik, siswa harus memiliki kemampuan berbahasa yang baik, salah satunya melalui pembelajaran menyimak yang efektif. Pendapat lain dikemukakan Karagoz, dkk., (2017:751) bahwa kegiatan menyimak adalah proses yang terjadi secara psikologis dan sosial dalam perkembangan kognitif melalui interaksi seseorang terhadap lingkungannya. Pedapat tersebut sejalan dengan konsep yang dikemukakan Ferrari-Brigers, dkk., (2017:1) yang mengasumsikan bahwa menyimak adalah keterampilan berbahasa yang terjadi secara alami. Pendapat tersebut memberikan pandangan yang berbeda tentang menyimak, namun pada hakikatnya konsep tersebut menguraikan bahwa kegiatan menyimak adalah 
keterampilan berbahasa yang digunakan dalam proses pembelajaran maupun kegiatan sosial.

Pembelajaran menyimak dongeng adalah salah satu materi yang diajarkan kepada siswa di SD/MI. Hadirnya materi dongeng dalam proses pembelajaran memberikan berbagai manfaat, salah satunya proses perkembangan karakter siswa. Sebagaimana dikemukakan Zaskia (2016:47) bahwa dongeng adalah salah satu cara yang paling efektif dalam mengembangkan aspek kognitif, afektif, sosial, dan penghayatan yang mendalam pada anak-anak. Majid (2013:9) menguraikan bahwa kegiatan menyimak cerita/dongeng adalah suatu proses mendengarkan cerita, yang mencakup kondisi pendengar, tingkat perhatian, tingkat keterpengaruhan isi cerita, sikap respek, dan gambaran jiwa terhadap pengaruh cerita yang disimak. Penyimak adalah seseorang yang secara langsung terlibat dalam proses mendegar cerita. Dari kegiatan menyimak tersebut diharapkan dapat memberikan kekuatan imajinasi seperti dari cerita yang disimak.

Sesuai dengan hasil observasi dan wawancara yang dilaksanakan di kelas III MIS Darul Ulum Muhammadiyah Bulukumba, pada dasarnya pembelajaran menyimak dongeng dikategorikan masih rendah. Hal ini sesuai dengan data hasil observasi yang menunjukkan bahwa rata-rata keterampilan siswa dalam pembelajaran menyimak masih di bawah standar KKM yakni di bawah nilai 70 . Rendahnya keterampilan siswa dalam pembelajaran menyimak dongeng, disebabkan oleh beberapa hal, yaitu: 1) siswa merasa kesulitan dalam mengidentifikasi isi yang terdapat pada dongeng, seperti menentukan tema, alur, karakter tokoh, dan amanat; 2) siswa tidak menunjukkan keseriusan dalam mengikuti pembelajaran menyimak dongeng, dan 3) metode yang digunakan oleh guru dalam pembelajaran menyimak kurang bervariasi, sehingga siswa tampak kurang memperhatikan penjelasan guru.

Mencermati berbagai permasalahan yang telah dikemukakan menjadi alasan penulis untuk melakukan penelitian di MIS Darul Ulum Muhammadiyah Bulukumba, khususnya dalam meningkatkan keterampilan menyimak dongeng. Salah satu cara dalam mengatasi permasalahan tersebut yakni dengan menerapkan media audiovisual dalam pembelajaran menyimak dongeng. Alasan penulis menggunakan media audiovisual, karena hal ini masih terkait dengan 
kondisi di sekolah tersebut, yakni selama ini guru belum pernah menggunakan media audiovisual dalam pembelajaran mendongeng.

Penggunaan media audiovisual dalam pembelajaran menyimak, khususnya menyimak dongeng, diindikasikan dapat memberikan stimulus yang kuat kepada siswa agar lebih mudah memahami isi cerita yang disimak. Sebagaimana dikemukakan Suryani, dkk., (2018:52) bahwa teknologi audiovisual adalah suatu teknik dalam menyampaikan materi melalui mesin-mesin mekanis dan elektronik, untuk menyampaikan pesan-pesan audiovisual agar orang mudah memahami dengan cepat. Pendapat tersebut sejalan dengan konsep yang dikemukakan Haryoko (2009:3) audiovisual adalah salah satu media yang dapat digunakan dalam menyampaikan informasi dengan karakteristik suara dan gambar. Dengan demikian, disimpulkan bahwa media audiovisual adalah suatu bentuk teknologi yang berfungsi sebagai alat dalam menyampaikan informasi dengan efektif agar seseorang mudah memahami maksud yang disampaikan.

Berdasarakan permasalahan dan konsep pemecahan masalah yang telah dirumusakan untuk meningkatkan keterampilan menyimak dongeng, penelitian ini didasari oleh beberapa penelitian sebelumnya terkait dengan pembelajaran menyimak maupun penggunaan media audiovisual. Penelitian yang pertama dilakukan oleh Rahayu (2013) dengan judul Peningkatan Keterampilan Menyimak Cerita Menggunakan Media Audiovisual Kelas V SD. Penelitian ini merupakan penelitian tindakan kelas yang dilaksanakan sebanyak dua siklus. Hasil penelitian ini menunjukkan bahwa aktivitas guru mengalami peningkatan pada siklus I yaitu 71,8 dan pada siklus II meningkat menjadi 88,3. Ketuntasan hasil belajar menyimak cerita dengan menggunakan media audiovisual juga mengalami peningkatan. Pada siklus I ketuntasan mencapai $68 \%$ dan pada siklus II mencapai $84 \%$. Dengan demikian, penggunaan media audiovisual dapat meningkatkan keterampilan menyimak. Persamaan penelitian Rahayu dengan penelitian penulis terletak pada penggunaan media audiovisual dalam pembelajaran menyimak dan metode penelitian yang digunakan yakni sama-sama menggunakan penelitian tindakan. Adapun perbedaan penelitian Rahayu dengan penelitian penulis terletak pada subjek maupun objek yang diteliti. 
Penelitian yang dilakukan oleh Istova (2016) yang berjudul Pengaruh Media Film Animasi Fiksi Islami untuk Meningkatkan Kemampuan Menyimak dan Berbicara Siswa Sekolah Dasar. Penelitian ini menggunakan metode kuasi eksperimen dengan desain control pretest dan posttest. Hasil penelitian tersebut menunjukkan bahwa saat dilakukan tes awal pada kelas eksperimen dan kelas kontrol masih sangat rendah. Setelah diberikan perlakukan, terjadi peningkatan pada kedua kelompok, baik kelas eksperimen maupun kelas kontrol. Namun, peningkatan lebih baik pada kelas eksperimen dengan menggunakan media film animasi fiksi islami dibandingkan dengan kelas kontrol yang hanya hanya menggunakan pembelajaran secara konvensional. Persamaan penelitian Istova dengan penelitian penulis terletak pada penggunaan media dalam pembelajaran menyimak. Adapun perbedaan penelitian Istova dengan penelitian penulis terletak pada subjek yang diteliti, penggunaan media pada penelitian Istova berupa film, hasil pembelajaran yang dicapai yakni pembelajaran menyimak dan berbicara, dan metode penelitian yang digunakan adalah eksperimen.

Selanjutnya penelitian yang dilakukan oleh Wuryani, Markamah, dan Sriyanto (2013) berjudul Penggunaan Media Wayang Kartun untuk Meningkatkan Keterampilan Menyimak Dongeng. Penelitian ini dilaksanakan pada siswa kelas II SD Negeri Dalangan 02 Tawangsari, Sokoharjo. Jenis penelitian yang dilakukan adalah penelitian tindakan kelas sebanyak 2 siklus. Hasil penelitian menunjukkan bahwa penggunaan media Wayang Kartun dapat meningkatkan keterampilan menyimak dongeng pada siswa kelas II SD Negeri Dalangan 02 Tawangsari. Peningkatan tersebut tampak pada hasil prasiklus, yakni nilai rata-rata keterampilan menyimak dongeng siswa sebesar 67,26 dengan persentase ketuntasan klasikal $41 \%$, siklus I rata-rata 73,91 dengan persentase $76 \%$, dan pada siklus II rata-rata sebesar 80,15 dengan persentase ketuntasan $88 \%$. Persamaan penelitian Wuryani dengan penelitian penulis terletak pada pembelajaran menyimak dongeng dan metode penelitian yang digunakan yakni sama-sama menggunakan penelitian tindakan. Adapun perbedaan penelitian Wuryani dengan penelitian penulis terletak pada subjek yang diteliti dan media yang digunakan dalam proses penelitian. 
Berdasarkan uraian pada latar belakang dan beberapa penelitian relevan, menunjukkan bahwa penelitian ini penting untuk dilakukan, khususnya pada siswa kelas III MIS Darul Ulum Muhammadiyah Bulukumba. Untuk itu, dalam penelitian ini akan menjawab rumusan masalah "Bagaimanakah proses dan hasil penerapan media audiovisual dalam meningkatkan keterampilan menyimak dongeng siswa kelas III MIS Darul Ulum Muhammadiyah Bulukumba? Dari hasil penelitian ini diharapkan bermanfaat terutama dapat dijadikan sebagai acuan bagi tenaga pengajar bahasa Indonesia agar pembelajaran keterampilan menyimak menjadi lebih efektif dengan menggunakan media audiovisual. Hal ini sesuai dengan peran tenaga pengajar bahasa Indonesia yang salah satunya yaitu harus mampu menciptakan pembelajaran yang kreatif dan berpikir kritis sehingga dapat mencapai tujuan pembelajaran yang diharapkan kurikulum (Noermanzah, 2015:274).

\section{B. Metode Penelitian}

Penelitian ini menggunakan metode penelitian tindakan (action research). Hopkins (dalam Muslich, 2009:8) mengemukakan bahwa penelitian tindakan adalah suatu bentuk kajian yang bersifat reflektif yang dilakukan oleh pelaku tindakan dalam meningkatkan kemampuan yang bersifat rasional demi memperdalam pemahaman-pemahaman mengenai kondisi dalam kegiatan praktik pembelajaran. Adapun rancangan penelitian tindakan dalam penelitian ini mengacu pada model yang dikembangkan oleh Kemmis dan McTaggart berupa model spiral. Pelaksanaan model ini mengacu pada beberapa tahapan yang dilaksanakan secara bersiklus yang meliputi tahap perencanaan, tindakan, observasi, dan refleksi dalam sistem spiral yang saling terkait (Sukardi, 2011:214).

Penelitian tindakan ini dilaksanakan di MIS Darul Ulum Muhammadiyah Bulukumba, dengan subjek penelitian adalah guru mata pelajaran bahasa Indonesia dan siswa kelas III yang terdiri atas 16 orang siswa. Pemilihan lokasi dan subjek dalam penelitian ini didasarkan atas beberapa alasan, diantaranya: 1) sekolah tersebut membutuhakn inovasi dalam proses pembelajaran dan 2) sesuai dengan kurikulum yang ada pada kelas III tentang materi dongeng. 
Teknik pengumpulan data yang dilakukan dalam penelitian ini adalah observasi, catatan lapangan, dan tes. Observasi digunakan untuk mengamati aktivitas siswa selama kegiatan menyimak melalui penerapan media audiovisual. Catatan lapangan digunakan untuk mengamati seluruh proses yang terjadi selama penelitian, mulai dari pembuatan rancangan pembelajaran sampai proses penerapan, sebagai bahan dalam kegiatan refleksi. Selanjutnya, tes digunakan untuk mengetahui keberhasilan pembelajaran tiap siklus. Tes ini dilakukan di setiap akhir siklus yakni pada pertemuan ketiga.

Teknik analisis data dalam penelitian ini ada dua, yaitu secara kualitatif dan kuantitatif. Secara kualitatif, data dianalisis dari hasil observasi dan catatan lapangan, sedangkan secara kuantitatif, data dianalisis dari hasil tes yang dilakukan di setiap akhir siklus. Selanjutnya, setelah dilakukan tahapan analisis data, ditentukan indikator keberhasilan dalam penelitian ini, yakni rata-rata hasil belajar siswa secara individu memperoleh nilai $\geq 70$ sesuai dengan batas minimal KKM mata pelajaran bahasa Indonesia di MIS Darul Ulum Muhammadiyah Bulukumba. Uji keabsahan data menggunakan triangulasi dari beberapa sumber data yaitu dari observasi, catatan lapangan, dan tes.

\section{Hasil Penelitian dan Pembahasan}

\section{Hasil Penelitian}

a. Proses Penerapan Media Audiovisual dalam Meningkatkan Keterampilan Menyimak Dongeng

Penelitian tindakan ini dilaksanakan pada bulan Februari sampai bulan Mei 2018 pada siswa kelas III MIS Darul Ulum Muhammadiyah Bulukumba. Proses pelaksanaan penelitian ini sebanyak dua siklus, yakni setiap siklus meliputi tahapan perencanaan, tindakan, observasi, dan refleksi. Adapun pemaparan data hasil penelitian pada siklus I dimulai dari hasil pengumpulan data observasi dan catatan lapangan. Beberapa hal yang dilakukan oleh peneliti dan guru dalam penelitian ini, dimulai dari tahap perencanaan dengan menganalisis permasalahan pembelajaran menyimak, menentukan standar kompetensi dan komptensi dasar, media yang akan digunakan, maupun penyesuaian materi pembelajaran. Setelah 
dilakukan tahapan analisis, selanjutnya membuat rancangan pembelajaran (RPP) untuk digunakan dalam pelaksanaan penelitian siklus I.

Pelaksanaan kegiatan pada siklus I sebanyak tiga kali pertemuan, yakni pada pertemuan pertama dan kedua berupa pemaparan materi dan proses latihan menyimak dongeng dengan menggunakan media audiovisual, sedangkan pada pertemuan ketiga yakni pelaksanaan tes menyimak dongeng. Sesuai dengan hasil pengamatan, tampak bahwa kegiatan pembelajaran dimulai dengan apersepsi dan penyampaian materi, selanjutnya pemutaran video dongeng yang berjudul "Sang Kancil dan Kerbau", untuk disimak oleh siswa. Setelah itu, siswa diminta untuk mengidentifikasi isi dongeng yang telah disimak, dengan menyebutkan judul, tema, tokoh dan penokohan, alur, dan amanat. Beberapa siswa masih tampak kesulitan untuk memberikan jawaban, namun beberapa siswa juga sudah sedikit memahami isi dongeng yang disimak, khususnya dalam menentukan tema, alur, latar, maupun amanat yang terdapat dalam cerita.

Selanjutnya pada pertemuan ketiga dilakukan tes menyimak dongeng melalui penerapan media audiovisual. Setelah guru melakukan kegiatan apersepsi, kemudian menanyakan kesiapan siswa untuk mengikuti tes menyimak. Kegiatan ini dimulai dengan pemutaran video dongeng sebanyak dua kali, setelah itu, siswa diminta untuk menuliskan tema, tokoh dan penokohan, alur, latar, dan pesan yang terdapat pada dongeng. Selama kegiatan berlangsung, peneliti mengamati proses pembelajaran yang terlaksana.

Tahap terakhir yang dilaksanakan pada siklus I yakni melakukan refleksi. Kegiatan ini dilakukan untuk mendiskusikan kelemahan-kelemahan yang terjadi selama proses pembelajaran berlangsung. Adapun hasil refleksi pada siklus I disimpulkan bahwa pembelajaran belum berjalan dengan maksimal. Beberapa hal yang menjadi permasalahan perlu dilakukan perbaikan, seperti kurangnya kesempatan yang diberikan siswa untuk mengajukan pertanyaan yang tidak dipamami, guru masih kurang pendekatan terhadap siswa yang tidak fokus, pemutaran video pada pertemuan pertama dan kedua sebaiknya diulang sampai tiga kali, beberapa siswa masih tampak ragu untuk menyampaikan jawaban, sehingga pada siklus berikutnya akan dibentuk kelompok-kelompok kecil, dan 
beberapa siswa masih tampak bingung dalam menggambarkan karakater tokoh dan penentuan alur cerita. Dengan demikian, pelaksanaan penelitian ini dilanjutkan ke siklus II, karena masih ditemukan beberapa kelemahan-kelemahan yang harus diperbaiki untuk meningkatkan keterampilan siswa dalam pembelajaran menyimak dongeng.

Pelaksanaan kegiatan pada siklus II sama dengan pelaksanaan siklus I yakni sebanyak tiga kali pertemuan, pada pertemuan pertama dan kedua berupa pemaparan materi dan proses latihan menyimak dongeng dengan menggunakan media audiovisual, sedangkan pertemuan ketiga dilaksanakan tes menyimak dongeng. Sesuai dengan hasil pengamatan, tampak bahwa pada pertemuan pertama, guru memulai dengan kegiatan apersepsi, penyampaian materi, dan membentuk kelompok kecil yang beranggotakan $2-3$ orang siswa. Selanjutnya pemutaran video dongeng yang berjudul "Si Kancil dan Buaya", setelah itu, siswa diintruksikan untuk mengidentifikasi isi cerita dan mempersentasikan di dalam kelompok. Pada kegiatan diskusi rata-rata siswa tampak memperlihatkan keseriusan, namun masih ada siswa yang masih tampak bermain dan mengganggu temannya, tetapi dapat diatasi dengan cepat oleh guru. Dari hasi persentasi siswa, tampak bahwa rata-rata siswa sudah mampu memberikan jawaban. Hal ini menunjukkan bahwa siswa cukup antusias mengikuti kegiatan pembelajaran.

Selanjutnya pada pertemuan ketiga dilaksanakan tes menyimak dongeng melalui penerapan media audiovisual. Setelah dilakukan apersepsi, guru kemudian menanyakan kesiapan siswa untuk mengikuti tes menyimak. Kegiatan ini dimulai dengan pemutaran video dongeng sebanyak dua kali, setelah itu, siswa diminta untuk mengidentifikasi isi dongeng dengan menuliskan tema, tokoh dan penokohan, alur, latar, dan pesan yang terdapat pada dongeng. Selama kegiatan berlangsung, peneliti mengamati proses pelaksanaan tes.

Tahap terakhir yang dilaksanakan pada siklus II yakni melakukan refleksi. Kegiatan ini dilakukan untuk mendiskusikan proses selama pembelajaran berlangsung, mulai dari pertemuan pertama sampai pertemuan ketiga. Adapun hasil refleksi pada siklus II disimpulkan bahwa pembelajaran sudah berjalan dengan baik. Walapun pada pertemuan pertama dan kedua masih ada siswa yang 
tampak bermain, tetapi dengan cepat guru mengalihkan perhatian siswa untuk tetap fokus mengikuti pembelajaran. Adapun pemutaran video dongeng dilakukan sampai 3 kali, kemudian siswa diminta untuk mengidentifikasi isi dongeng yang disimak, dan terbukti cara tersebut mampu dipahami dengan baik oleh siswa. Dengan demikian, disimpulkan bahwa pelaksanaan penelitian ini berakhir pada siklus II, karena proses pelaksanaan pembelajaran sudah berjalan dengan baik. Adapun kekurangan-kekurangan yang terjadi, dapat menjadi kegiatan tindak lanjut bagi guru dan menjadikan penelitian ini sebagai dasar perbaikan untuk pembelajaran selanjutnya.

b. Hasil Penerapan Media Audiovisual dalam Meningkatkan Keterampilan Menyimak Dongeng

Sesuai dengan hasil pelaksanaan keterampilan menyimak dongeng melalui penerapan media audiovisual pada siklus I diperoleh nilai rata-rata sebesar 61,75, nilai maksimal 72, dan minimal 48. Adapun hasil pencapaian keterampilan menyimak dongeng pada siswa kelas III dapat dilihat pada tabel berikut.

Tabel 1. Distribusi Frekuensi Nilai Keterampilan Menyimak Dongeng pada Pelaksanaan Tes Siklus I

\begin{tabular}{cccc}
\hline No. & Interval Nilai & Jumlah Mahasiswa & Persentase (\%) \\
\hline 1. & $40-49$ & 1 & 6,25 \\
\hline 2. & $50-59$ & 5 & 31,25 \\
\hline 3. & $60-69$ & 5 & 31,25 \\
\hline 4. & $70-79$ & 5 & 31,25 \\
\hline 5. & $80-89$ & - & - \\
\hline & Jumlah & 16 & $100 \%$ \\
\hline
\end{tabular}

Berdasarkan hasil pelaksanaan teks siklus I, sesuai dengan data distribusi frekuensi pada Tabel 1 menunjukkan bahwa siswa yang mencapai nilai ketuntasan atau yang memperoleh nilai $\geq 70$ yakni hanya 5 orang siswa dengan persentase $31,25 \%$, sedangkan siswa yang mencapai nilai tidak tuntas sebanyak 11 orang dengan persentase 68,75\%. Masih rendahnya keterampilan siswa dalam menyimak dongeng disebabkan karena beberapa siswa belum mampu memahami dengan baik alur cerita yang disimak. Selain itu, beberapa siswa juga belum mampu mengungkapkan dengan jelas karakter setiap tokoh yang ada dalam cerita. Disimpulkan bahwa hasil pelaksanaan tes siklus I pada pembelajaran 
menyimak dongeng melalui penerapan media audiovisual siswa kelas III MIS Darul Ulum Muhammadiyah Bulukumba belum maksimal, karena masih banyak siswa yang memperoleh nilai di bawah standar KKM, sehingga penelitian ini dilanjutkan ke siklus II.

Hasil pelaksanaan keterampilan menyimak dongeng melalui media audiovisual pada siklus II diperoleh nilai rata-rata 76,25 , nilai maksimal mencapai 88, dan minimal 68. Adapun hasil pencapaian keterampilan menyimak dongeng pada siswa kelas III dapat dilihat pada tabel berikut.

Tabel 2. Distribusi Frekuensi Nilai Keterampilan Menyimak Dongeng pada Pelaksanaan Tes Siklus II

\begin{tabular}{cccc}
\hline No. & Interval Nilai & Jumlah Mahasiswa & Persentase (\%) \\
\hline 1. & $40-49$ & - & - \\
\hline 2. & $50-59$ & - & - \\
\hline 3. & $60-69$ & 4 & 25 \\
\hline 4. & $70-79$ & 5 & 31,25 \\
\hline 5. & $80-89$ & 7 & 43,75 \\
\hline & Jumlah & 16 & 100 \\
\hline
\end{tabular}

Berdasarkan hasil pelaksanaan teks siklus II, sesuai dengan data distribusi frekuensi pada Tabel 2 menunjukkan bahwa siswa yang mencapai nilai ketuntasan atau yang memperoleh nilai $\geq 70$ yakni sebanyak 12 orang siswa dengan persentase $75 \%$, sedangkan siswa yang mencapai nilai tidak tuntas sudah mengalami penurunan yakni hanya 4 orang dengan persentase $25 \%$. Hasil pencapaian tersebut menunjukkan bahwa perolehan nilai siswa mengalami peningkatan dari hasil sebelumnya. Dengan demikian, disimpulkan bahwa hasil keterampilan menyimak dongeng melalui penerapan media audiovisual sudah dikategorikan baik, karena sebagian besar perolehan nilai sudah mencapai ketuntasan, sehingga penelitian ini berakhir pada siklus II.

Selanjutnya persentase ketuntasan hasil keterampilan menyimak dongeng siswa, mulai dari hasil pelaksanaan tes siklus I sampai hasil tes siklus II mengalami peningkatan yang baik. Data selengkapnya tampak pada tabel dan diagram berikut.

Tabel 3. Rekapitulasi Nilai Keterampilan Menyimak Dongeng pada Siswa Kelas III MIS Darul Ulum Muhammadiyah Bulukumba

\begin{tabular}{cccc}
\hline No. & Tahap & Tuntas & Tidak Tuntas \\
\hline 1. & Siklus I & $5(31,25 \%)$ & $11(68,75 \%)$ \\
\hline 2. & Siklus II & $12(75 \%)$ & $4(25 \%)$ \\
\hline
\end{tabular}

Silampari Bisa: Jurnal Penelitian Pendidikan Bahasa Indonesia, Daerah, dan Asing Vol. 1, No. 2, 2018 


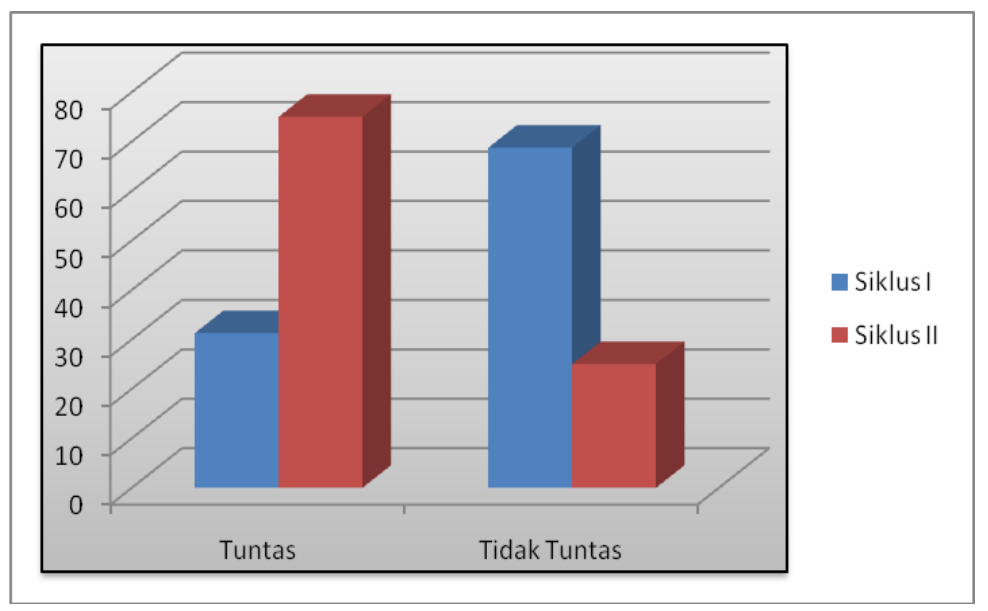

Gambar 1. Rekapitulasi Nilai Keterampilan Menyimak Dongeng pada Siswa Kelas III MIS Darul Ulum Muhammadiyah Bulukumba

\section{Pembahasan}

a. Proses Penerapan Media Audiovisual dalam Meningkatkan Keterampilan Menyimak Dongeng

Berdasarkan pelaksanaan pada siklus I diuraikan bahwa proses pembelajaran belum berjalan dengan maksimal. Berbagai hal yang menyebabkan pembelajaran belum berjalan secara maksimal tampak dari kurangnya kesempatan yang diberikan kepada siswa untuk mengajukan pertanyaan yang tidak dipamami, guru masih kurang pendekatan terhadap siswa yang tidak fokus, beberapa siswa masih tampak ragu untuk menyampaikan jawaban, sehingga pada siklus berikutnya dibentuk kelompok-kelompok kecil, dan beberapa siswa masih tampak bingung dalam menggambarkan karakater tokoh dan penentuan alur cerita. Adapun kendala siswa dalam mengidentifikasi isi dongang yang disimak yakni masih sulit menentukan tema, sebagian besar siswa menganggap tema sama dengan judul. Selain itu, siswa juga tampak kesulitan dalam menentukan alur cerita. Dengan berbagai kendala tersebut, maka ditekankan bahwa diperlukan penguasaan materi terlebih dahulu sebelum siswa ditugaskan untuk mengidentifikasi isi dongeng yang disimak. Hal ini belum maksimalnya menggunakan media audiovisual dengan maksimal. Bukan permasalahan media audiovisualnya, karena media audiovisual menurut Suryani, dkk., (2018:52) bahwa 
teknologi audiovisual mampu menyampaikan materi melalui mesin-mesin mekanis dan elektronik, untuk menyampaikan pesan-pesan audiovisual agar orang mudah memahami dengan cepat. Untuk itu, pada siklus II dimasimalkan penggunaan media audiovisual dengan lebih kontekstual, bervariasi, dan inovatif lagi.

Adapun proses pelaksanaan pada siklus II tampak bahwa selama proses pembelajaran berlangsung menunjukkan proses berjalan dengan baik. Walapun masih ada beberapa siswa yang tampak bermain, tetapi dengan cepat guru mengalihkan perhatian siswa untuk tetap fokus mengikuti pembelajaran. Selain itu, kemampuan siswa dalam mengidentifikasi isi dongeng sudah cukup baik, hal tersebut tampak bahwa yang sebelumnya siswa rata-rata mengalami kesulitan mengidentifikasi tema dan alur, namun pada siklus II, rata-rata siswa sudah mampu. Dengan demikian, disimpulkan bahwa pelaksanaan penelitian ini berakhir pada siklus II, karena proses pelaksanaan pembelajaran sudah berjalan dengan baik.

b. Hasil Penerapan Media Audiovisual dalam Meningkatkan Keterampilan Menyimak Dongeng

Berdasarkan hasil pelaksanaan penelitian ini, menunjukkan bahwa keterampilan siswa dalam menyimak dongeng mengalami peningkatan. Hasil tersebut tampak dari perolehan nilai rata-rata pada siklus I hanya sekitar 61,75, nilai maksimal, 72 , dan nilai minimal 48 , sedangkan hasil pelaksanaan pada siklus II mengalami peningkatan dengan perolehan nilai rata-rata 76,25 , dengan nilai maksimal mencapai 88, dan minimal 68. Hasil tersebut memberikan gambaran bahwa penggunaan media audiovisual dalam pembelajaran menyimak dongeng memberikan dampak positif dalam peningkatan hasil belajar siswa. Hal tersebut ditandai dengan kemampuan siswa dalam mengidentifikasi isi dongeng yang disimak, seperti menentukan tema, karakter tokoh, alur, latar, maupun amanat. Hasil penelitian ini sesuai dengan konsep yang dikemukakan Suryani, dkk., (2018:52) bahwa audiovisual merupakan salah satu media yang digunakan untuk menyampaikan pesan agar orang mudah memahami dengan cepat informasi yang diungkapkan.

Adapun persentase ketuntasan hasil keterampilan menyimak dongeng siswa, mulai dari hasil pelaksanaan tes siklus I sampai hasil tes siklus II Silampari Bisa: Jurnal Penelitian Pendidikan Bahasa Indonesia, Daerah, dan Asing Vol. 1, No. 2, 2018 
mengalami peningkatan yang signifikan. Seperti yang tampak pada data hasil penelitian menunjukkan bahwa pada pelaksanaan tes siklus I diperoleh persentase ketuntasan hanya $31,25 \%$, sedangkan yang tidak tuntas mencapai $68,75 \%$. Setelah dilakukan perbaikan sesuai dengan hasil refleksi, maka pada pelaksanaan siklus II mengalami peningkatan, dengan persentase ketuntasan mencapai $75 \%$, sedangkan yang tidak tuntas hanya $25 \%$. Dengan meningkatnya keterampilan siswa dalam menyimak, dapat disimpulkan bahwa penelitian ini memberikan hasil yang positif bagi proses pembelajaran, sehingga penelitian ini berakhir pada siklus II. Hal ini sejalan dengan penelitian yang dilakukan Rahayu (2013) bahwa media audiovisual dapat meningkatkan hasil pembelajaran menyimak, yang ditandai dengan meningkatnya aktivitas guru dan siswa setiap siklus selama kegiatan pembelajaran berlangsung.

\section{Simpulan}

Hasil penelitian ini dapat disimpulkan bahwa terjadi peningkatan kemampuan keterampilan menyimak dongeng dengan penerapan media audiovisual pada siswa kelas III MIS Darul Ulum Muhammadiyah Bulukumba. Hal ini dibuktikan setelah diterapkan media audiovisual nilai siswa pada keterampilan menyimak meningkat terutama dari siklus I ke siklus II. Peningkatan tes siklus I diperoleh persentase ketuntasan hanya $31,25 \%$ dan pada siklus II mengalami peningkatan dengan tingkat persentase mencapai 75\%. Dari segi proses setelah dilaksanakan tindakan sampai pada siklus II tampak bahwa kegiatan pembelajaran berjalan dengan baik, karena rata-rata siswa menunjukkan sikap antusias dalam mengikuti proses pembelajaran. Selain itu, hasil tersebut juga ditandai dengan meningkatnya kemampuan siswa dalam mengidentifikasi isi dongeng seperti, tema, karakter tokoh, alur, latar, dan amanat. 


\section{Daftar Pustaka}

Ampa, A. T. (2015). The implementation of interactive multimedia learning materials in teaching listening skills. English Language Teaching, 8(12), 56. Doi:10.5539/elt.v8n12p56.

Ferrari-Bridgers, F., Stroumbakis, K., Drini, M., Lynch, B., \& Vogel, R. (2017). Assessing Critical-Analytical Listening Skills in Math and Engineering Students: An Exploratory Inquiry of How Analytical Listening Skills Can Positively Impact Learning. International Journal of Listening, 31(3), 121141. Doi: 10.1080/10904018.2016.1222910.

Haryoko, S. (2009). Efektivitas pemanfaatan media audio-visual sebagai alternatif optimalisasi model pembelajaran. Jurnal Edukasi Elektro, 5(1).

Istova, M., \& Hartati, T. (2016). Pengaruh Media Film Animasi Fiksi Islami untuk Meningkatkan Kemampuan Menyimak dan Berbicara Siswa Sekolah Dasar. Jurnal Pendidikan Sekolah Dasar, 2(1), 72-86.

Karagöz, B., Iscan, A., Baskin, S., \& Irsi, A. (2017). Investigation of Turkish Teacher Candidates Listening Skills. Universal Journal of Educational Research, 5(5), 750-756. Doi: 10.13189/ujer.2017.050507.

Kirbas, A. (2017). Effects of Cooperative Learning Method on the Development of Listening Comprehension and Listening Skills. Online Submission, 5(1), 117. Doi: 10.18298/ijlet.1712.

Majid, A. A. A. (2013). Mendidik dengan Cerita. Bandung: Remaja Rosdakarya.

Muslich, Masnur. (2009). Melaksanakan PTK Penelitian Tindakan Kelas Itu Mudah. Jakarta: Bumi Aksara.

Noermanzah, N. (2015). Peran Dosen Bahasa dan Sastra Indonesia dalam Mempertahankan Bahasa Indonesia sebagai Alat Pemersatu Negara Kesatuan Republik Indonesia pada Era Globalisasi. In Prosiding Seminar Nasional Bulan Bahasa 2015. Unit Penerbitan FKIP Universitas Bengkulu, p. 274. http://repository.unib.ac.id/11133/

Rahayu, I. (2013). Peningkatan Keterampilan Menyimak Cerita Menggunakan Media Audio Visual Kelas V SD. Jurnal PGSD. Surabaya: Universitas Negeri Surabaya, 1(2).

Sukardi. (2011). Metodologi Penelitian Pendidikan Kompetensi dan Praktiknya. Jakarta: Bumi Aksara. 
Suryani, N., Setiawan, A., \& Putria, A. (2018). Media Pembelajaran Inovatif dan Pengembangannya. Bandung: Remaja Rosdakarya.

Wuryani, M. T., Markamah, E. S., \& Sriyanto, M. I. (2013). Penggunaan Media Wayang Kartun untuk Meningkatkan Keterampilan Menyimak Dongeng. Jurnal Didaktika Dwija Indria, 1(8).

Yanti, N., Suhartono, S., \& Hiasa, F. (2018). Keterampilan Menulis Akademik Mahasiswa S 1 Program Studi Pendidikan Bahasa dan Sastra Indonesia FKIP Universitas Bengkulu. Silampari Bisa: Jurnal Penelitian Pendidikan Bahasa Indonesia, Daerah, dan Asing, 1(1), 2. doi:10.31540/silamparibisa.v1i1.4

Zaskia, S. (2016). Anak Hebat Berkat Hipnodongeng: Panduan Hipnodongeng dalam Mendidik Anak. Yogyakarta: Laksana. 